
ERRATUM.-In the BRITISH MEDICAL JodRNAL for January 218 it was
stated that Surgeon-Lieutenant-Colonel MELLAIEw had proceeded from Gited that Surgeon-Lieutenant-Colonel MELLAYEW had proceeded from Co'nnel. "I "ICARTNEY, M.D. Dr. Melladew remains with the Royal Horse Guards.

INDIAN MEDICAL RERVICE.

The services of Surgeon-Captains L. G. Fischer and L. J. PISANI, of the Bengal Establishment, are placed permanently at the disposal of the G ivernment of the North-West Provinces and Oude. Surgeon-Captain in, on return from eave, is posted to Jounpore District.

Surgeon-Lieutenant-Colonel C. H. JOUBERT, M.B., Bengal Establishme it, has been appointed a Fellow of the University of Calcutta.

Surgeon-Major K. M. DowNIE, M. D., Bengal Establishment, is promoted to be Surgeou-Lientenant-Colonel from December 29th, 1892. He was appointed Assistant-Surgeon October 1st, 1868; Surgeon, July 1st, 1873 Exoedition in 1885.87 (medal with clasp, and in the Hazara Expedition in 1828 (clasp)

Surzeon-Captain A. H. NoTT, Bengal Establishment, officiating Civil gu rgeon of Beerbhoom, is appointed to act as Civil Surgeon of Hazareebagh.

surgeon-Captain P. C. H. BTRICKLaND, Madras Establishment, Civil surgeon of Chanda, Central Provinces, is appointed to the Medical and Executive charge of Chanda Gaol.

Surgeon-Captain E. C. HARE, Bengal Establishment, officiating Civil Surgenn of Belaspore, Central Provinces, is appointed to the Medical and Executive charge of Belaspore Gaol.

Surgenn Captain W. D. SuTherLAND, Madras Establishment, Civil Surgeon of Dumoh, Central Provinces, is appointed to the Medical and Exeutive charge of Dumoh Gaol.

Surgeon Major R. PEMBERTON, Madras Establishment, is appointed to as Civil Surgeon of Cochin.

Brigade-Surgeon-Lieutenant-Colonel D. F. BATEMAN, Madras Establishwith temporary rank of Surgeon-Colon, Madras, is appointed to officiate the districts in the Madras command, dated December 27th, 1892 .

Surgenn-Major A. J STORMER, Madras Establishment, has returned from furlough out of India.

Burgeon-Captain C. DoNovas, M.D., Madras Establishment, is appointed to the Medical charge of the 10th (1st Burmah Rifles) Madras Infantry.

Surgeon-Captain 1. P. DoYLE, D.S.O., Madras Establishment, is appointed to the officiating Medical, charge of the 27th Madras Infantry.

Surgeon.Major A F. FERGUSON, M. B. Bombay Establishment, is appointed Civil surgeon of Shikarpore, vice Surgeon-Captain J. Crimmin, December 23 rd, 1892

Surgeon-Lieutenant-Colonel G. W. R. HAY, M.D., Bombay Establishment, is promoted to be Brigade-Surgeon-Lieutenant-Colonel from December 3rd, 1892, vice Brigade-Surgeon-Lieutenant-Colonel J. Davidson, retired. Dr. Hay was appointed Assistant-Surgeon April 1st, 1868; Surgeon, Colonel, April 1st, 1889 .

Surgeon-Major W. A. BARREN, Bombay Establishment, in medical charge 16th Bombay Infantry, is appointed to the Medical charge of the Bombay Sappers and Miners, vice Brigade-Surgeon-Lieutenant-Colonel J. Davidson, retired.

Surgeon-Major HoRACE DAY, M.D. Bombay Establishment, retired, died at Los Gatos, California, on January 16th, aged 59.

\section{THE VOLUNTEERS}

Mr. JOHN BANKs, M.B, is appointed Surgeon-Lieutenant to the 1st Argyll and Bute Artillery, February 4th.

Surgeon-Lieutenant Colonel J. S. PERKrNs, 1st Devonshire Artillery was dated February 18t, 1889, his appointnient as Surgeon dating from was dated February 1

Surgeon-Captain J. J. A. V. C. RAYE, from the 1st Durham Volunteer Surgeon-Captain J. J. A. V. C. RAYE, from the 1st Durham Volunteer Artilery (Western Division Roval Artillery), is appointed Surgeon.Cap2nd Oxfordshire), February 4th.

Mr. ARCHER TILLYER CóLUM is appointed Surgeon-Lieutenant to the 13th Middlesex (Queen's Westminster), February 4th

Surgeon.Lleutenant J. ADAM, M.D., ist (Ross Highland) Volunteer Battalion Seaforth Highlanders (Iate the 1st Ross-shire), is promoted to be Surgeon-Captain, February 4th.

Surgeon-Major $W$. PATERSON, 4th Volunteer Battalion Gordon Highlanders (late the 4th Aberdeenshire), is promoted to be Surgeon-Lieutenant-Colonel; and Surgeon-Lieutenant A. NICOL, M. D., of the same corps, is promoted to be Rurgeon-Captain, both dated February 4th. Quartermaster S. H. NIXoN, London Companies' Volunteer Medical
Staff Corps, is granted the honorary rank of Captain, February lst.

\section{THE NEW TITLES}

A CorRespondent states when he joined the head quarters of a district lately he had eimply $M r$. - on his cards : but finding the officers of the headquarter staff, and also their wives, socially address him as " Captain ;" and that his brother officers were also addressed by the military portion of their compound titles, he took his proper title of surgeon-Captain; but soon found that was objected to, as too cumbrous. The obvious solution of these cross purposes is plain military titles in a Royal Corps.

\section{VOLUNTEER OFFICERS' DECORATIONS}

YET another list of officers who have received the new decoration is contained in the London Gazette of February 3rd, and this list includes the following gentlemen: Surgeon Richard S. Fowler, 1st Volunteer Battalio 等 guke of Cornwall's Light Infantry.
NON-COMBATANT VOLUNTEERS AND THE DECORATION. THE correspondent who informed us, as stated in the BRITISH MFDICAL JOURNAL of December 24th, 1892, that he has good authos ity for aserting that a more or lessiconfidential order had been issued, direcling that only in special and exceptional cases were the names of non-combatant (including medical) volunteers to be submitted for the decoration, gives us further assurances of the correctness of his information. . At the time we treated the rumour of the issue of any such order as incredible, in view of its gross injustice; but in holding such an opinion we by no means impugned the veracity or bona fides of our correspondent, but only the possible accuracy of his information. He cannot, indeed, divulge publicly the source of his information, but'offers to put us privately on the right track; for his informant says that "the exclusion of non-combatant volunteers" (from the decoration) "except in special cases is a fact." This is a fit subject for a question in Parliamenú, and we trust explanation will be demanded.

INDIAN ECONOMIES.

KOOCH PERWANI writes: The Indian papers are constantly writing about the "dearth of doctors," and how the medical service is being gradually starved out. At many large stations there is only one senior medical officer, and when he waits leave is met by the answer: "Oh, we cannot spare an experienced man like you." "Suppose serious trouble arises on the frontier or elsewhere, where, in the face of persistent and recklos
be?

** Yes; where?

VOLUNTEER PROFICIENCY EXAMINATION.

SURGEON-LIEUTENANT asks: What books should be read and known for the efficiency examination, now required of all surgeo

** For the proficiency examination the chief book required is the Regulations for the Medical Department of the Army, the important sections being as follows: Part 1. (General Duties) Sections I, II, III (i, ii, iv, and v). Part 2. (Army Hospitals) Sections I, V, VII, and IX (i, vil, viii, ix, x, xi, xii, and xili). Part 3. (Diets). Part 5. Section II (Medical Inspection of Recruits). Part 6. (Sanitary Duties) especially vaccination and infectious diseases. Also the Appendices relating to Hospital Diet Tables; Cholera Epidemics; Disinfectants and Fumigation; Personnel of Hospitals and Bearer Company ; Contents of Field Companion and Surgical Haversac. A knowledge of stretcher drill and of the various improvised methods of conveying wounded is also required at most stations. Sleman's Manual for the Votunteer Medical Service (P. G. Keliher and Co.) (2s.) will also be found useful.

PRIVATE MEDICAC PRACTITIONER'S BILL FORM.

SURAEON NOT CHEMIST writes he had the above Army Form (0. 166i) handed to him to fill in for attendance on a soldier's family, but after several trials gave it up in disgust.

* * The form alluded to is that which a private practitioner claims i receives charges for attendance on soldiers and their families in the absence of a military medical officer. The instructions on the back are decidedly rather antiquated, and we think might be modernised. But of course it is absolutely necessary to specify the scale of charges, as all as to limit the amount, as these accounts are carefully audited in the interests of the public purse.

\section{THE INDIAN SUBORDINATE MEDICAL SERVICE.}

INDIAN WARRANT MEDICAL OFFICER writes: In your article on Indian Economies I do not think you are fully informed regarding the case in question or of the position occupied by the subordinate medical service. The warrant medical officer, or apothecary as he is more generally styled, goes through precisely the same curriculum in college as students for the degree in medicine; and the period of study has lately been increased from three to four years. The general education test, too, or admission to the service by competition at the age of 16 , is almost equal to that required for registration in England. After severe examination they receive a certificate or diploma entitling them to practise medicine and surgery ; and their progressive attainments are tested by two additional examinations during their service. To all intents and purposes, therefore, they are fully qualified geveral practitioners, and are so recognised throughout India. In the substitution quoted at the Lawrence Asylum, that school is only $2 \frac{1}{2}$ miles from the large station of Kasauli, where several commissioned medical officers
are or lately were stationed, who would be available in any time of

** We can assure our correspondent we do not write on these matters without the very best information. For instance, our correspondent is probably not aware that it was officially reported that the civil surgeon at Kasauli could not be made available for any duty at the Lawrence Asy. lum. We can fully appreciate the merits and qualifications of the subordinate medical service, and yet hold that on many'grounds of state policy it cannot be substituted for the commissioned service be. yond a certain point without detriment to the general administration of India. The warrant officers of the Commissariat, Engineers, and other branches of the service are a most important and.' necessary 